\title{
INVOLVEMENT OF SPECIALISTS IN INVESTIGATIVE ACTIVITIES IN THE INVESTIGATION OF CRIMINAL OFFENSES
}

\section{Pyrih I. V.}

\section{INTRODUCTION}

At the present stage of the formation and development of the Ukrainian state there are major processes of transformation of socioeconomic and political relations, which take place in difficult conditions, characterized by high levels of crime, including its organized forms, criminalization of the economy and other spheres of society. One of the main tasks of criminal justice is to ensure the speedy, complete and impartial investigation of crimes. To solve this problem, the investigator, the prosecutor, the court must take all the measures provided by law, applying their knowledge and experience. However, only legal knowledge is not enough to solve these problems.

The development of modern science, and, above all, the applied sciences, which include forensics, due to the interpenetration of knowledge, the use of advanced methods of other sciences to solve the challenges facing law enforcement agencies. It is impossible to imagine the process of investigation of crimes without the use of the achievements of natural, technical and other sciences. It is also impossible to imagine a modern investigation without the use of the latest advances in scientific and technological progress and the scientific and technological means developed on their basis. Therefore, it is no coincidence that the term scientific category «special knowledge», which embodies the knowledge itself is not a legal profile, originated in the theory of criminal justice and occupies a decisive place among the main categories of criminalistics. Therefore, in order to properly solve the problem of combating crime, to investigate every crime in a timely and qualitative manner, not only the professional knowledge and skills, which are formed on the basis of a complex of scientific knowledge, the experience of 
investigating crimes, but also special knowledge from other rapidly developing fields, are required thanks to scientific and technological progress. The above determines the relevance of forensic trends in the development of forensics.

Researchers have offered many definitions of specialist knowledge used in criminal justice. Considering the majority of the opinions expressed by scientists that sufficiently reveal the essence, purpose and directions of the use of special knowledge, let us mention the basic criteria for defining the concept of special knowledge. First of all, when determining special knowledge, it should be borne in mind that: 1) special knowledge is non-legal, except for the above, that is, knowledge that is not professional for the investigator, employees of the operational units, the prosecutor, the judge; 2) must be based on the achievements of science, not be generally known; 3) by the method of obtaining special knowledge is acquired either by theoretical assimilation of certain information, or by periodic practical training by a separate type of work; 4) the purpose of using specialized knowledge is to facilitate the resolution of criminal justice tasks.

Summarizing, you can define the scientific category «special knowledge». Specific knowledge - a set of theoretical knowledge and practical skills in science, technology, arts or crafts acquired as a result of professional training or professional experience used to investigate and prevent crime. At the present stage, there is no consensus on the forms of use of specialized knowledge, its quantity, procedural regulation, content and classification. We join the opinion of scholars who share the forms of using specialized knowledge for procedural and non-procedural ones ${ }^{1}$. Procedures should be considered procedural such as are expressly provided by law, namely: a) the participation of a specialist in criminal proceedings; b) forensic examination. Non-procedural should be considered special

1 Аверьянова Т. В., Белкин Р. С., Корухов Ю. Г., Россинская Е. Р. Криминалистика. Учебник для вузов. Под ред. Заслуженного деятеля науки Российской Федерации, профессора Р. С. Белкина. М. : Издательство НОРМА, 2000. С. 398; Гончаренко В. И. Использование данных естественных и технических наук в уголовном судопроизводстве (методологические вопросы) : монография. К. : Вища школа, 1980. С. 109. 
knowledge not outside the criminal process, and those that are not expressly provided by law. Such forms are: a) departmental investigations, inspections of technical condition; b) conducting site studies directly at the scene; c) consultative help; d) providing technical assistance in the preparation of technical equipment, the implementation of labor-intensive work; e) the use of assistance of knowledgeable persons in conducting operational search activities.

The legislator allows the application of any kind of specialized knowledge in the fields of science, technology, arts and crafts. This is quite true, since criminal law rules regulate a large number of social relations, and knowing the causes and circumstances of their violation in the investigation process may require the application of different specific knowledge, experience and skills. Equally important is the fact that humanity in its development is constantly enriched with more and more knowledge in various fields, so it is impossible to provide a comprehensive list of them in law. Consider one of the most important procedural forms of the use of specialized knowledge, namely the participation of a specialist in conducting investigative actions.

\section{Involvement of specialists in the inspection of the scene}

Pre-trial investigation is carried out within the limits and with clear regulation of norms of the Criminal Procedure Code of Ukraine. According to the forms of use of specialized knowledge and the legislation in force, the subjects who possess them are an expert (Article 69) and a specialist (Article 71). According to Article 71 of the Criminal Procedure Code of Ukraine, «a specialist in criminal proceedings is a person who possesses specialized knowledge and skills in the application of technical or other means and can provide advice during pre-trial investigation and judicial review on issues requiring relevant specialized knowledge and skills. The specialist may be involved in providing direct technical assistance (photographing, drawing up schemes, plans, drawings, sampling for examination, etc.) by the parties to criminal proceedings during the 
pre-trial investigation and the court during the trial» ${ }^{2}$. The same article outlines the rights of the specialist and the duties assigned to him.

Based on the procedural status of the investigator as the main and independent procedural figure in the pre-trial investigation, the specialist should be considered in terms of his or her auxiliary status in the activity of the subject of investigation. The investigator may involve any specialist, depending on the type of specialist knowledge required in the conduct of any particular investigative action. The main criterion for the selection of specialists to participate in investigative activities is the availability of relevant specialist knowledge.

Forensic investigators are most often involved in criminal experts, who are employees of the pre-trial investigation bodies of the National Police or the Ministry of Interior's Expert Service. According to the Instruction on the procedure for involving police officers and the Expert Service of the Ministry of Internal Affairs of Ukraine as specialists to participate in the inspection of the scene, approved by the order of the Ministry of Internal Affairs of Ukraine dated 03.11.2015 No. 1339, specialists are «forensic inspectors, criminal investigators forensic inspectors, forensic technicians, and in the case of the creation of sectors of forensic technical support of investigative actions - heads of these sectors, which are part of the of the pre-trial investigation bodies, and the staff of the Ministry of the Interior's Expert Services within the Specialized Mobile Laboratory, who have specialized knowledge and can advise during the pre-trial investigation on issues requiring special knowledge and skills involved in assisting technical assistance proceedings during the pretrial investigation» ${ }^{3}$.

\footnotetext{
${ }^{2}$ Кримінальний процесуальний кодекс України від 13.04.2012 р. № 4651-17. URL: http://zakon4.rada.gov.ua/laws/show/4651-17.

${ }^{3}$ Про затвердження Інструкції про порядок залучення працівників органів досудового розслідування поліції та Експертної служби Міністерства внутрішніх справ України як спеціалістів для участі в проведенні огляду місця події : наказ МВC України від 03.11.2015 № 1339. URL : https://zakon.rada.gov.ua/laws/show/z1392-15.
} 
A review is an investigation that involves the direct perception of objects in order to identify the trace of a crime and other material evidence, to clarify the circumstances of the event, as well as the circumstances of the case ${ }^{4}$. The review is one of initial, unique and irreplaceable investigative action. When inspecting the scene, they look at all objects that may be relevant to the crime, depending on the particular investigative situation, the investigator's internal conviction. Therefore, the informative nature of the investigative review is much higher than other investigative actions.

The review is governed by Articles 237-239 of the Criminal Procedure Code of Ukraine. The general rules and conditions for conducting an investigative review are set out in Article 237: «In order to identify and record information about the circumstances of a criminal offense, an investigator, a prosecutor, conduct an inspection of the area, premises, things and documents». The same article provides for the participation of a specialist in conducting an investigative action and outlines tasks that fall within the competence of a specialist: «In order to obtain assistance on issues requiring special knowledge, an investigator, a prosecutor may invite specialists to participate in the examination. When inspected, an investigator, prosecutor, or on behalf of an expert involved, has the right to make measurements, take pictures, sound or video record, make plans and diagrams, produce graphic images of the site or individual things, make prints and casts, inspect and remove things and documents that are relevant to criminal proceedings»». These actions of the investigator and the specialist are carried out to solve the tasks of the inspection in order to establish the circumstances of the crime. Depending on the type of crime, the circumstances to be determined, investigated and proved are specific, but the most typical of them determine the following: whether the crime occurred; whether the crime was committed where the scene was inspected; what are the ways of entry of persons to the scene, ways of their departure, vehicles, where the traces indicate, which can be used to organize the persecution; the number of persons present at the scene,

4 Криміналістика: Підручник для студентів юрид. спец. вищих закладів освіти / Глібко В.М., Дудніков А.Л., Журавель В.А. та ін. / За ред. В.Ю. Шепітька. К.: Видавничий Дім “Ін Юре”, 2001. С. 217. 
their characteristics; during which time the event participants were at the scene; the time of the crime; which point of the territory or premises being inspected is the scene of the incident in which the offender and the victim were injured at the time of the personal injury; what derivative actions were taken at the scene (hiding or tampering with the tracks); what traces of the scene remained on the offender and others. Most of these problems can be solved only after a thorough study of the situation of the scene, which is why many experts are involved.

During the examination and exhumation of a corpse (Articles 238, 239 of the Criminal Procedure Code of Ukraine), the presence of a forensic specialist is mandatory, as forensic experts of the Ministry of Health of Ukraine are in practice. Specialist assistance is required at all stages of the investigation in conducting such vigorous investigative activities: inspection (Article 237) - almost mandatory; interrogations (Article 224), search (Article 234), presentation for identification (Articles 228, 229, 230), investigative experiment (Article 240), examination (Article 241), appointment of expertise (Article 242), specimens for examination (Article 245) - if necessary.

Types of specialist assistance are divided into forensic, advisory, methodological and technical. Forensic assistance consists in the preparation, organization and conduct of certain investigative action; detection, fixation, removal of evidence, selection of samples for expert study. The methodological assistance is to clarify the conduct of investigative action by a specialist terminology used in a particular field of knowledge, the correct names of the removed objects or parts of them. Sometimes, when drawing up the report, the investigator records this information under the dictation of a specialist. In providing this assistance, the investigator acquires new special knowledge, enhances his professional experience. Technical assistance is to assist the investigator in the use of forensic tools in the process of investigative actions; examination, detection, fixation, removal of physical evidence; drawing up diagrams, drawings and the like. Advisory assistance is expressed in verbal explanations, references on special issues that may arise or arise in the preparation and conduct of investigative actions, and the procedural design of their results. The forensic specialist provides all these types of assistance. 
In our opinion, the actions of forensic specialists, depending on the stage of the review, are sufficiently regulated by the Instruction on the procedure for involving police officers and the Expert Service of the Ministry of Internal Affairs of Ukraine as specialists to participate in the inspection of the scene ${ }^{5}$. The main tasks of forensic specialists are contained in clauses 3-12 of the Instruction: «3) at the beginning of the examination the investigator together with the specialists shall determine the boundaries and the procedure for conducting the examination, after which the specialist shall take pictures and video of the scene; 4) after receiving the order of the investigator for the dynamic stage of the inspection of the scene and the task of revealing trace information, the specialists determine the algorithm for finding evidence (traces, things, documents) and methods of their discovery, and then coordinate their actions with the investigator and proceed with his consent location inspection; 5) actions of specialists directly related to the detection, consolidation and seizure of traces and physical evidence are carried out in accordance with the tactics of the scene inspection and the method of investigation of certain types of criminal offenses; 6) a specialist takes a photograph of the object before moving the object (in order to view and discover trace information); 7) during the search and trace detection specialists use the available technical means and first of all use non-destructive methods of their detection, and in case of failure to achieve a positive result - destructive methods of detection of trace information; 8) prior to the use of destructive methods of trace search, specialists must obtain the investigator's consent to their use and determine the priority of traceable information to be detected in order to carry out expert research in laboratory conditions; 9) Specialists inform the investigator about the measures taken and the facts of revealing trace information. During the inspection, the objects are photographed and removed, and the methods of their detection are recorded, with an indication of this in the location inspection report; 10) during fixation of detected trace information in the protocol,

5 Інструкція про порядок залучення працівників органів досудового розслідування поліції та Експертної служби МВС України як спеціалістів для участі в проведенні огляду місця : затв. наказом МВС України від 03.11.2015 р. № 1339. URL : https://zakon.rada.gov.ua/laws/show/z1392-15 
specialists assist the investigator in describing specific traits (type and number of traces detected, their localization, method of detection); 11 ) if possible, the traces are removed together with the trace objects. If it is impossible to remove trace information with the object of the carrier, the specialist takes their photographing according to the rules of large-scale photography and making copies (prints and prints) of these traces. All trace information, bearing objects and other objects are packed with the help of a specialist in accordance with the established requirements and passed on to the examining officer; 12) the specialist is responsible for the quality and completeness of the orders received from the investigator or the head of the pre-trial investigation body during the inspection of the scene».

The crime scene specialist should act in close collaboration with the investigator and other members of the investigation team. The interaction of the investigator with the survey participants begins at the preparatory stage before the departure to the scene, which gives an opportunity to find out in advance the composition of the investigation team and the professional capabilities of the staff. In preparation for the inspection of the scene at the invitation of the investigator, the forensic specialist participates in the discussion of available information about the crime event, the procedure of the foreseen actions during the inspection of the scene, expresses his opinion on the expediency of involving other specialists and the use of technical means. Having received information about the event of the crime, the specialist prepares the necessary tools, instruments, reference materials before commencing specific actions and assisting the investigator.

The team leader is definitely an investigator. But in the field of collecting traces and other material evidence is more competent forensic specialist, who has special knowledge that is missing from the investigator. Therefore, the advice of the specialist on the organization, progress and results of work with the trace should be taken into account by the investigator. It is important for a forensic specialist to be tactically competent in constructing their work during the inspection of the scene. Reviewing the venue for each particular event has its own peculiarities, but the work of a forensic specialist is almost always reduced to a predefined algorithm of actions. 
First of all, upon arriving at the scene, the specialist is convinced that the organized protection of the scene, together with the investigator, determines the limits of the inspection and takes measures to ensure that no outsiders stay within these limits. Determining the boundaries of the survey is usually carried out simultaneously with the orientation and survey photography. He then, along with the investigator and the notion, who are strictly on the path already traveled by a specialist, gradually bypasses the area within the inspection, identifying, fixing and removing traces and other material evidence from the surface of the floor or soil on which to step and which can be changed or destroyed in the advance of the Investigation Team.

Thus freeing up the corridor to move through the territory of the scene, the specialist, possibly with a person informed about the usual location of objects (the owner of the apartment, a materially responsible person in the store, etc.), bypasses this territory, while finding out which of the objects previously located, missing, customary locations, etc. If it is not possible to use the testimony of the specified persons, the specialist does this work independently, determining the change of position of objects or their absence on visible or visibly visible traces (anomalous location of objects, dusty traces of layers, peeling, broken web, scratches on the surface, etc.). According to the crawl, the specialist, analyzing the traces, signs of movement of persons, objects, etc., makes his own idea of what happened - a model of the event, from which he determines the predicted locations of invisible traces and begins to process all visible, poorly visible and invisible traces that, from his point of view, are relevant to the event of the crime. Identity of detected objects and traces to the event is established during their preliminary study, taking into account their location and positioning, prescription, etc. Consistently working out the territory of the inspection, passing from node to node, the specialist detects, fixes, removes, packs the traces in accordance with established requirements. At the general inspection stage, the forensic specialist, without disturbing the environment, makes orientation, survey and nodal photographs. The tactical tasks of applying the location photograph are determined in consultation with the investigator. The technical parameters of 
photography (lighting, exposure selection, etc.) are determined by a specialist.

When conducting a general overview, care should be taken not to disturb the situation, to destroy existing traces and to leave their own. It is strictly forbidden at this stage of the review (static stage) to change the situation of the scene. During the detailed examination phase, the forensic specialist uses the most effective methods and means of detecting, fixing and removing traces and objects. At this stage of the review (dynamic stage), the position of the objects being inspected can be modified and technical means facilitated to detect traces and enhance the contrast of their images can be used.

At this stage of the review, the forensic specialist performs the following actions:

- consistently and comprehensively examines the details of the location of the event, the nodes that were conditionally broken into the event during the general inspection, as well as each detected object and should be separately;

- on the location of the tracks, taking into account the meteorological conditions, etc., determines whether or not the traces were found at the time of the crime;

- when inspecting, take items so as not to damage the traces and leave them, possibly using gloves;

- identifies traces and objects to be deleted;

- Measures footprints and objects viewed at the scene;

- determines the techniques and selects scientific and technical means by which traces and objects found at the scene can be secured and removed;

- makes detailed photographing of traces and objects found.

The final stage of the scene inspection is characterized by the fact that the forensic expert helps the investigator to remove, pack, following the precautions, traces and objects found in order to ensure their preservation during transportation for further investigation. The best way to remove traces and objects is to remove them along with the media object. Pursuant to Article 71 of the Criminal Procedure Code of Ukraine, a specialist is acquainted with the report of the investigative action and has the right to make observations subject to entry in the report. When working at the scene, a forensic expert 
assists the investigator in drawing up the inspection report by providing him with the following information regarding his work:

- where, on what surface, on which object or substance traces are found;

- indicates the type of trace according to conventional classification (volumetric, surface, static, dynamic, visible, invisible, etc.);

- configuration and size (length, width, depth) of the tracks;

- what objects or parts of objects are left behind;

- characteristic features of trace-forming objects that appeared in the traces;

- if traces are superficial (layering or peeling), what kind of substance (dust, dirt, paint, etc.) they are formed by;

- the location and relative position of the tracks (if any) and the distance between them;

- what damage is found in the traces during inspection;

- methods for detecting, fixing and removing traces with a description of the techniques and methods used.

The description of the traces found must be made in full and in such a way that the description can always distinguish these traces from others.

A forensic specialist may be practically unlimited in time in the course of his / her work at the scene, especially when it comes to reviewing particularly serious crime scenes. However, he can also be put in a tight frame when, for a limited period of time, he is required to take part in several visits to places, so to speak, «ordinary» crimes: theft from apartments, cars and the like. The tactics of his work with traces in such situations are different. In the first case, it fulfills all traces, both unconditionally suitable and those whose suitability or unsuitability can be established only in laboratory conditions, which in its view may be relevant to the event of the crime. Otherwise, in order to save time and still achieve a positive result, he needs to put maximum emphasis on those traces that are almost certainly left behind by the offender and whose suitability is indisputable. These traces can most often be found in the nodal areas of the scene, such as in penetration points.

Forensic experts or doctors are obliged to be involved in the examination of the corpse and may be involved at the discretion of 
the investigator in the investigation of serious or moderate bodily injury and other crimes related to harm to human health. In the case of personal injury, most often they are doctors who go to the emergency medical team. They provide medical assistance to victims and sometimes suspects detained at the scene; provide the investigator with primary information about the injuries, their location and the severity. Psychologists may be hired as staff psychologists at the scene by National Police departments or medical doctors to assist the victim at the scene, possibly in a state of shock.

The specialist-cynologist at the scene: 1) in agreement with the investigator determines the boundaries of the inspection of the scene and the procedure for its identification in order to identify the traces and objects that are relevant for the use of a service dog, based on the available information determines the feasibility of its use; 2) take measures to search and apprehend a person who has committed a criminal offense, by using a service dog on odor tracks, things and objects left at the scene, and in order to find traces and objects that are relevant for the detection and investigation of a criminal offense; 3) participates in the blocking of the place of commission of the criminal offense, its inspection, detection, fixing, removal and storage of objects and traces that can be used for the search of the person who committed the criminal offense using a service dog; 4) indicate the places of detection on the way of the service dog's pursuit of objects and things that can be used to search the person who committed the criminal offense with the use of the service dog; 5) informs the head of the investigative-operational group of information about the possible origin of odor carriers (traces, objects) detected at the scene and their use for the detection and investigation of a criminal offense; 6) using the information received, use a service dog to search the person who has committed a criminal offense, following its odor trails; 7) inspect with the help of a service dog the territory and possible places of concealment of the person who committed the criminal offense (attics and basements of adjoining buildings that are not a dwelling or other possession of the person, open storehouses, forest parks, careers, etc.); 8) together with other police officers 
involved in the prosecution and detention of persons suspected of committing a criminal offense, use a service $\operatorname{dog}^{6}$.

Kennel specialists are involved to assist in the search for the offender on the odor trail. Occasionally, there are some items left behind by the suspect that are odor carriers. The involvement of a search dog and a canine dog leads to positive results, especially in small towns and villages. However, unfortunately, the National Police in Ukraine does not make full use of the capabilities of cynologists, as evidenced by the results of the interrogation of investigators.

At the present stage, crime is becoming more professional. Modern crime tools are used, leaving traces that are difficult to detect. Given the complexity of crime investigations in the current context, it is promising to involve not only a forensic specialist but a group of specialists in different narrow-area knowledge fields. Positive is the experience of conducting an inspection of the scene by the US police. The detective works with a group of specialists, which consists of a photographer who takes photo, video shooting; Specialists in the extraction of evidence, depending on their type: trasological, biological, ballistic, etc.; analyst; event reconstruction specialist. Each specialist is certified by their field of activity in specialized institutions, which have the right to train relevant specialists. For example, a specialist photographer receives a certificate from Evidence Photographers International Council, Inc., a specialist typist from the International Association for Identification ${ }^{7}$. These specialists are not police officers and are involved in conducting a site inspection by appointment.

Another argument in favor of the proposal to conduct a site-ofevent review by a group of specialists is the improvement of forensic equipment that the investigator is unable to master on his own. Also, their simultaneous application with the drafting of the review protocol

6 Інструкція про порядок залучення працівників органів досудового розслідування поліції та Експертної служби МВС України як спеціалістів для участі в проведенні огляду місця : затв. наказом МВС України від 03.11.2015 р. № 1339. URL : https://zakon.rada.gov.ua/laws/show/z1392-15.

7 A Simplified Guide to Crime Scene Investigation. National Forensic Science Technology Center, September 2013. URL: http://www.forensicsciencesimplified.org/csi/how.html. 
is almost impossible and impractical. Successful use of modern forensic technology requires not only specialist knowledge but also certain skills. For example, a camcorder is used to capture an event, with continuous video of circular panoramas of the event location. Using this camera at various levels allows you to cover all possible locations of evidence, and software allows you to zoom in and out of objects $^{8}$. In the long run, in our opinion, using the above video footage in general may refuse to draw up a review protocol. Multicopter (quadcopter) equipped with camcorders with appropriate software may be used to capture the situation of a large event location in an open area (such as a place of fire or accident).

\section{Involvement of specialists during the search}

Another investigation, which in most cases requires specialist help, is search. During the investigation, in practice, there are problems regarding the organization of involvement of specialists in the search, the amount of work performed by him, interaction with the investigator and other participants in the investigation, the limits of the use of specialized knowledge, etc. That is why consideration of these issues is relevant, first of all, for the practice of investigating crimes.

The search is an investigative action, «the content of which is the compulsory examination of premises and structures, areas of the territory, of individual citizens for the purpose of finding and removing items of importance in the case, as well as identifying wanted persons $»{ }^{9}$. The search is conducted in accordance with Articles 233-236 of the Criminal Procedure Code of Ukraine. A specialist is involved with the investigator to assist in the search. The assistance of experts in the course of the search is to facilitate the identification, consolidation and removal of evidence. It manifests itself in the following services: collecting information that helps to

${ }^{8}$ Crime Scene Camera Kits + Reconstruction Software. CSI: 360: веб-сайт. URL: http://www.csi360.net/360-crime-scene-cameras.php (дата звернення 01.05.2019).

${ }^{9}$ Криміналістика : підручник для студ. юрид. спец. вищих закладів освіти / кол. авторів : [Глібко В. М., Дудніков А. Л., Журавель В. А. та ін.] ; за ред. В. Ю. Шепітька. К. : Видавничій Дім «Ін Юре», 2001. С. 290. 
prove the identity of the objects found to a specific person; identifying, fixing, and removing traces, objects, and substances that will continue to be the subject of expert study; compilation of orientations (search tables) for searchable objects; application of scientific and technical means (search devices, lamps of UV and infrared illumination, etc.) and in the prevention and prevention of damage to objects, environment and traces as a result of inappropriate handling.

In most cases, forensic knowledge is required to conduct the search, as forensic experts are involved. The scientific literature sometimes focuses on the need to involve in the search of individual specialists, for example, with the possible removal of weapons specialist ballistics, traces of biological origin - specialist biologist, narcotic drugs - specialist chemist, etc. But in practice, even with careful preparation for the search, it is sometimes impossible to anticipate all the specialized knowledge that may be required and to bring in the necessary specialists in a timely manner. In our opinion, this is not necessary, since forensic science, namely knowledge of forensic techniques, which are considered special, cover a wide range of different industries. The forensic expert involved in the search can remove various traces on his own.

The main task in the activity of a specialist during the search is to find the subject, which is known that he is of interest to the case and probably is in this place. Then inspect the object found, record all traces of the crime, and describe and remove it. Traces on the objects found during the search can be handprints, microparticles of metal, trees on the tools of breakage; residues of substances of biological origin: blood, saliva, epidermis, urinary matter; liquid substances: gasoline, lubricants, foodstuffs on clothing and items used in their abduction; layering of soil and other substances (bricks, cement, coal) on clothing and footwear; the smell of man and the like. Forensic inspectors have the necessary knowledge to extract any of the items or traces identified. An exception is the involvement of explosive technicians in cases of searches with the removal of explosives and devices, as well as with the anticipation of possible passage of approach paths or the site itself.

Let us dwell on some of the problematic moments of the specialist's activity during the search. When removing items during a 
search, questions often arise about proving their belongings to the suspect. This generally applies to objects that are prohibited for free use (weapons, drugs, high-power, explosives, etc.), or stolen items. A qualified inspection of the objects discovered during the search will reveal the traces of the perpetrator's or the victim's fingers, microparticles and micro-traces, which can establish the fact of their transfer by a specific person, or storage in the place from where they were stolen. Therefore, it is important to alert the investigative team to the precautionary search prior to the search and seizure of identified items. Sometimes, during the briefing of the group, the investigator does not pay proper attention to the search. The specialist must explain to the attendees the rules of handling search objects, depending on their types.

The results of the search largely depend on the correct determination of the relation of the detected objects to the crime. During the search, the investigator does not always know exactly what particular items can be used in the further evidence, and it is often impossible to determine by external evidence. In this case, the investigator consults with a specialist. For example, these may be devices specifically designed to break obstacles («crowbars», locks), or atypical firearms disguised as household items, etc.

Specialist assistance is also necessary in the selection of objects, which can then be used as specimens in the appointment and conduct of examinations (tracological, technical examination of documents, handwriting, etc.). Yes, handwritten texts belonging to the suspect may be removed, which will then serve as free samples when conducting a forensic examination; printing technique, printers, samples of paper, forms of documents, paints, stamps, which could be used in the forgery of documents - in carrying out technical examination of documents. Among the instruments or tools found, a specialist may find, on certain grounds, the tools of the burglary that will be sent for tracological examination or the weapon or its workpiece, for ballistic examination.

It is traditional to help a specialist in refining the protocol, adjusting the schemes and plans that are being drawn up. Within the limits of his specialist knowledge, he assists the investigator in describing in the protocol the objects and traces to be removed, the peculiarities of their detection, removal and fixation, paying attention 
to the means by which they were found; individual characteristics of objects, the names of their individual parts; photo and video features.

The specialist is also involved in photography and video recording. The rules of their conduct are traditional and do not need special discussion. Let us mention only that the most important is the fixation of the moment when the objects and documents are removed, as well as the places of their storage. Given the dynamic nature of the search, its active search orientation, it is advisable to accompany it with video recording. At present, the best option is to consider a combination of technical fixation: video recording with taking pictures of the items being removed. Modern digital photo and video technology enables video capture and photography almost simultaneously, using the same technical means. The investigator acts as the organizer of the search and the leader of the actions of all its participants, he directs the process of conducting the investigative action and at the same time records the progress of its conduct in the record. Therefore, he does not have too much time to use any technical devices, including modern photo, video equipment.

\section{Participation of experts in questioning and investigative experiment}

The interrogation is the most widespread and important investigative action, but also the most difficult one. The interrogation takes $25 \%$ of the investigator's total working time and $80 \%$ of the investigator's time spent in conducting the investigative activities ${ }^{10}$. Therefore, it is no coincidence that considerable attention was paid to the problems of questioning.

The success of an interrogation depends on many factors. First of all, from the personality of the main participant of the interrogation the investigator. From his experience, knowledge, intuition, general and professional culture, and in some cases, a certain talent, the completeness and accuracy of the information obtained about the facts relevant to the investigation depends. The current conditions of counteraction to crime require an increasing skill of the investigator,

${ }^{10}$ Весельський В. К. Сучасні проблеми допиту (процесуальні, організаційні і тактичні аспекти) : монографія. Київ : НВТ «Правник». НАВСУ, 1999. С. 3. 
especially in the investigation of crimes in such areas of human activity as industrial production, entrepreneurship, banking, transportation and more. These industries require the use of investigators to investigate not only publicly available information but also specialized knowledge. In today's context of changing the structure of crime and increasing the professionalism of criminals themselves, investigators are increasingly seeking the help of specialists. Involvement of experts during the interrogation facilitates the more effective conduct of the investigative action by obtaining from the interrogated maximum amount of information needed to establish the truth.

During the interrogation, the amount and varieties of special knowledge required are determined by the investigator depending on the type of crime, the person being interviewed, the method of committing the crime, the amount of material evidence collected, etc. The investigator can involve specialists from the preparatory stage. At this stage, it is a matter of examining the specific issues that may arise during the interrogation, determining the range of circumstances to be clarified; study of the interviewee's personality; determining the location, situation, time and manner of the call for questioning; determining the number of participants in the questioning; preparation of necessary materials and choice of technical means of fixation; drawing up an interrogation plan. The investigator can get advice on these issues from a specialist in the preparation for interrogation.

A specialist can assist in formulating questions that may further depend on the course of the investigation. For example, in criminal proceedings for theft from a warehouse, the brackets of the padlock were snacked. The suspect testified that he did it with wire cutters. The investigator did not pay attention to their designs and did not involve the specialist who examined the castle in the questioning. Subsequently, during the search of the suspect's premises, the investigator seized the locksmiths and assigned an expert examination concerning the identification of questions. In the course of the further investigation, it was found out that when committing the crime, railway clippers were used, which the suspect took from his stationmate, a co-conspirator. The negative results of the search and the 
appointment of the examination led to a waste of time and effort and an unjustified delay in the investigation.

At the preparatory stage of the interrogation, after deciding to recruit a specialist, the investigator will inform the latter of the interrogation plan. In doing so, the specialist makes adjustments to the plan, which, in his opinion, are appropriate. These may be additional questions regarding the specific knowledge, quantity and location of the technical means of fixation. The tactics of the interrogation are also discussed and the organizational aspects of the specialist's actions are specified: the expected moment of commencement of the actions, their character, the marks of the investigator and his reaction to the actions of the specialist.

Thorough preparation for questioning and consultation with experts often do not eliminate the possibility of being caught in a difficult position, as the respondent's answers are sometimes unexpected for the investigator. In such a situation, one has to interrupt the interrogation, consult again with knowledgeable persons, study the necessary literature, delaying the investigation time, adversely affect the establishment of objective truth in the case, and in addition, contradict the principles and objectives of criminal justice. Therefore, it is advisable to use the assistance of specialists directly during the investigation. By their actions, they assist the investigator in identifying and fixing evidence, namely: to better, more accurately and more fully understand the interrogator who uses special terms in the testimony; Understand the applicable special rules, instructions and other documents; to establish a way of committing criminal acts; suspend false testimony concerning special issues; to record by technical means the progress and results of the interrogation.

The participation of a specialist in the interrogation is required in the following cases:

- very complex provisions should be explored concerning any area of knowledge which the investigator is not able to absorb in the term given for the pre-trial investigation;

- Special Knowledge Interrogation does not apply to difficult situations but relates to episodes of circumstances; 
- despite the fact that the investigator has mastered the basic provisions of this field of knowledge, he may find it difficult to find out the details, options and decisions in each of them;

- the future interrogation will relate to the provisions related to specialized knowledge, and the interviewee, according to the investigator, has a very high level of professional training and work experience.

Today, more and more suspects, and sometimes witnesses, refuse to give their testimony during the investigation or trial. This raises the question of the objectification of the information obtained during the interrogation. Therefore, a specialist should be added to this list to clarify the content of the information provided by the interviewee, detail the explained processes and phenomena, individualize the characteristics of certain objects that require the use of specialized knowledge. For example, a person interviewed in detail with the assistance of an explosive technician will be able to describe how and by what means an improvised explosive device was manufactured. The results of an interview with the participation of a specialist engineer-technologist will be more reliable, when the interviewee will explain the essence of technological operations that led to the formation of unnecessary products in case of theft of property.

In the work phase, as a rule, the specialist begins to actively participate in the questioning after finding out the questionnaire to the investigators, explaining the rights and obligations to those present and listening to the testimony of the interviewee in the form of a free story. The specialist listens carefully to his explanation on the merits of special issues and makes notes when necessary, but he does not interfere in the interrogation, even if the interviewee reports deliberately incorrect information. However, if the questioning is conducted in the form of questions and answers, the specialist will often intervene in the questioning after the investigator has found out everything he has planned. The questions are asked by a specialist with the permission of the investigator, and relate not only to the details on which the interviewee reported incorrect information, but also to any information not well known to the investigator, for which special knowledge is required.

Effective tactical methods of interrogation are the presentation during the investigation of objects, documents or other material 
evidence removed during other investigative actions. In some cases, it may also be advisable to make known the interrogated information contained in the investigation protocols. During the interrogation, it is possible to announce the findings of the expert reports, the results of individual investigative actions, which indicate the possibility of the interrogated person at the crime scene. In order to implement these tactics, it is advisable to involve a forensic specialist who seized or investigated material evidence or participated in some investigative action.

Presentation of material evidence to a suspect is usually done in order to expose his or her false testimony. When using tactical admission, it is important to show evidence of what can help. Presentation of evidence with the participation of a specialist is more effective, because during the demonstration the specialist can apply the necessary technical means to show certain properties of objects or to study them. For example, it may point to a forgery in the financial statements, explain the method of execution and the mechanism of forgery, and demonstrate its features identified in a previous or expert study. The results of such presentation prompt the interviewee to tell the truth about the circumstances of the forgery, the materials used, their location, the persons who made him or her, their accomplices. Knowing that the testimony can be immediately verified, the person interviewed will try to tell the truth. Demonstration of physical evidence also evokes associative links in the interviewee's memory, prompting him to recall new details and facts.

Activation of associative relationships occurs in the interviewee also during questioning at the scene. Re-perception of the situation can restore the forgotten. Conducting an on-site interrogation does not preclude the interrogated protocol from being presented to the interviewee with applications in the form of diagrams, photo tables, drawings. At this point, the specialist involved in the examination may assist the witness or suspect giving the true testimony, navigate the spot, correctly indicate the direction of the offender's movement or the location of the crime traces. When questioned by a suspect in a conflict situation, a specialist can help to refute the false testimony by 
explaining the contents of the protocol and comparing it to the actual situation of the scene.

As an expert in the interrogation, it is sometimes advisable to involve an expert who has carried out the expertise in this case, if its conclusion is presented to the suspect. The specialist explains and argues the specifics of the research process and the conclusions of the examination, the nature of the detected signs of objects, the content of photo tables and other illustrations. For example, in the interrogation of a suspect in the theft of goods by rail - an accomplice of a criminal group who worked as a pickup truck at the station - counterfeit documents were presented for a coal wagon in the train. The bill of lading and the waybill were forged by the signatures of the officials and the text that filled out the form. At the beginning of the interrogation, he categorically denied his involvement in the event. After the expert presented the results of the handwriting examination with the corresponding explanations, which indicated that the text was written in the documents personally by him, and the execution of the signatures by not the persons who had to certify the documents, the interviewee began to give a true testimony.

It is important if the interviewee is able to draw certain objects that were used in the crime. According to the drawing, a forensic specialist can give a preliminary conclusion about the type of weapon or model of the weapon. If the testimonial person has no drawing skills, then a specialist can photograph objects. Immediately thereafter, the specialist will inform the investigator of the characteristics of the used tools or model of the weapon. This information may be used in the investigation.

When questioning witnesses and victims who have remembered and described the perpetrator's appearance, it is advisable to involve a specialist portrait artist, but this is not always possible. In this case, a forensic specialist is involved, who will help to describe the criminal's appearance by drawing up a composite portrait. This is especially effective in a conflict-free situation where psychological contact with the interrogated by the investigator is established. The resulting image may be attached to the proceedings in addition to the interrogation protocol. 
In addition to the positive impact of specialist involvement on the effectiveness of the interrogation, and hence the effectiveness of the entire investigation, the specialist has traditionally provided technical assistance. Sound information is essential for interrogation, so practically no interrogation photography is used. Sound and video recording are especially important. It is advisable to use audio, video recording when conducting certain types of interrogation: a minor, interrogation with the assistance of a translator, etc. The purpose of the application during the interrogation of audio and video recording is as follows: a) ensuring the completeness of fixation of what the interviewee reports; b) refutation of allegations of falsehood in the recording of testimony; c) a deterrent effect on the change of position.

The most effective, especially during complex interrogations, is video recording. It not only allows you to hear the statements of the interviewee, but also to monitor his or her reaction, and can also solve a number of problems related to attempts to challenge the results of the interview. Yes, in practice it is often possible to encounter a refusal during the trial of testimony previously given during the interrogation. Reasons for such refusals are references to the influence of law enforcement agencies either before or directly during the interrogation or the interrogation of a person in temporary mental disorder. When watching a video, it becomes immediately apparent that there was a physical impact during the interrogation, if any. According to the same videos, it is possible to assign a psychopsychiatric examination to determine the presence and consequences of psychological influence on the part of the persons conducting the investigative (search) action and present during its conduct. In the same way, by the manner of language and behavior while giving testimony, one can conclude that there are any forms of influence prior to the initiation of investigative (investigative) action or the state of temporary mental disorder of the interviewee.

Conducting an investigative experiment as a separate investigative action is envisaged by Article 240 of the Criminal Procedure Code of Ukraine, which states that «in order to verify and clarify information relevant to establishing the circumstances of a criminal offense, the investigator, the prosecutor shall have the right to conduct an 
investigative experiment by reproducing the action, circumstances, circumstances of a particular event, conducting the necessary experiments or tests» ${ }^{11}$. This article also explicitly refers to the possibility of participation in the conduct of this investigative action of the specialist: «if necessary, the investigative experiment may be conducted with the participation of a specialist. Measurement, photography, sound or video recording, plans and diagrams, graphical images, prints and footprints that can be added to the protocol can be made during the investigative experiment». In most cases, investigators of the National Police are involved in the investigation of crimes.

In forensic science, scientists note different types of investigative experiment depending on its purpose, namely the establishment of:

- possibility of observation, perception of any fact, phenomenon;

- the possibility of carrying out any action under certain conditions;

- the presence or absence of specific professional skills and competences;

- the ability to perform certain actions at certain times;

- the sequence of development of a particular event and mechanism of the crime or its individual elements;

- the limits of the person's awareness of the facts of interest to the investigation $^{12}$.

Specialists are involved to assist the investigator when they need to use the specialized knowledge they possess. Specialist assistance is required in the following cases:

- selection of the most appropriate for solving a specific task of the type of experiment;

- planning of the experiment taking into account the optimal tactics of its conduct and the scientific and technical means and methods used;

11 Кримінальний процесуальний кодекс України від 13.04.2012 p. № 4651-17. URL: http://zakon4.rada.gov.ua/laws/show/4651-17.

12 Чаплинський К. О. Тактичне забезпечення проведення слідчих дій : монограф. Д. : Дніпроп. держ. ун-т внутр. справ; Ліра ЛТД, 2010. С. 426-427. 
- selection of objects, objects that will be used during the experiment;

- creating special conditions for the experiment;

- recreation of the situation and circumstances of the event for conducting experiments;

- carrying out the most experimental actions to ensure their technical and methodological correctness;

- recording the progress and results of the experiment by taking pictures and / or video recording;

- correct reflection of the progress and results of the experiment in the investigative report;

- evaluation of the results of the experiment.

As evidenced by the practice of investigation of crimes, most often criminal investigators are involved in the investigative experiment. They mainly perform the task of the investigator to fix with the help of photo, video equipment of the course and the results of the investigative experiment. Among others, car mechanics are involved in the investigation of traffic-related crimes (in almost $90 \%$ of cases). When investigating computer-related crimes, the appropriate specialists are involved in investigating a person's ability to use certain programs and to perform certain actions using a computer.

Specialist assistance is usually needed during the investigative work phase. However, they may also be involved in the preparatory phase. At this stage of the investigative experiment, specialists are involved in:

- drawing up a plan of investigative experiment, the purpose of which is to check the advanced versions, to compare the data obtained by examination and other investigative actions in case of their inconsistency;

- determination of tactical and technical methods for carrying out the experiment, as a result of which self-defense, a mistake in recognizing a person or object can be established;

- the selection of persons to be replaced in the experiment by the suspect, a witness;

- determination of actions that will help to reveal undetected circumstances of the case, traces of the crime; 
- selection of tools, objects, vehicles that will be analogues of real ones;

- production of models, models of criminal assault;

- the selection of scientific and technical means, taking into account the tasks that will need to be solved during the investigative experiment.

The analysis of the criminal proceedings materials and the results of the survey of investigators indicate that from the mentioned possibilities of involvement of specialists at the preparatory stage, they participate only in the selection of tools, objects, vehicles, etc. that can be used during the investigative experiment, or which can serve as analogues valid. In addition, this applies only to complex, repetitive experiments (for example, in cases involving a traffic accident). On the one hand, such statistics are negative because the involvement of specialists in the preparatory phase takes less time both to prepare and to carry out investigative action. However, if the actions of the specialists are able to be performed by the investigator himself or his assistant, it may not be necessary to involve the specialists directly at the preparatory stage. For the more rational allocation of time for the investigator and the specialist, in most cases, it is necessary to limit the involvement of specialist knowledge at the preparatory stage of the investigative action in the form of consultations.

The activity of a specialist during a content experiment consists of two separate types: fixation of the course of the investigative action and detection and removal of traces of crime. Sometimes these actions cannot be performed at the same time. In such cases, it is advisable to involve two specialists. One of the specialists is shooting video. The other detects and removes traces of the crime during the course of the investigation, demonstrates them in front of the camcorder in general form and individual details, conducts their detailed examination and preliminary research if necessary, draws the investigator's attention to the identified individual features of objects and so on. If necessary, he also takes a photo of the location of the testimony and the detected objects. 
The features of the video include the following. At the beginning of an investigative (search) action, the person whose testimony is being examined should briefly explain at what point the event took place and what exactly took place there. Audio recording of readings is important at this stage. It is made on a camcorder, while it is advisable to use a remote microphone. Before moving to the area where the events took place, the video recording is stopped by the investigator's team and resumes upon arrival. From now on, it is recommended to stop video recording, as emphasized by numerous methodological guidelines for the use of video recording in the course of investigative actions. It is possible to move participants over long distances, for example within a village. We have processed more than a hundred videos of on-site testimony. More than half of them have footage depicting a street or a section of the area where investigators are moving, with no trace of a crime, and no event information can be retrieved from the video. Such recordings sometimes last for 1520 minutes. Of course, such a shooting is done by a specialist for convenience, behind the group of participants, resulting in a corresponding video. While processing the videos, we met even those who had unreasonably recorded the moment of placing the participants in the car and the way of its movement to the scene. In such cases, it is necessary, at the initiative of a specialist, to stop the video recording, to select the location of the new recording in front of the group of participants at one of the central venues of the event, and then to continue shooting again. By doing so, we will get more informative video and save time for acquaintance with the video materials of the investigator, other participants of the investigative action, and further participants of the process - the prosecutor, the defense lawyer, the judge, etc.

The main tactical technique for conducting an investigative experiment in the form of an on-site testimony is a demonstration by a person whose testimony is verified by his own actions «with prejudice». On this basis, an important rule in video-recording of this investigative action is the recording when the story goes beyond the indication of the situation in question. Orienteering and survey photography may be possible before approaching participants. If an 
object featured in the previous readings is detected on the route, a street name plate, house name, store name, pillar number, individual tree, etc. must be removed using the camera lens zoom. Also, the object to which the person providing the information to be checked is recorded. At the scene relevant to the event under investigation, the video is recorded according to the venue inspection rules. In addition to recording directly the actions of the person whose testimony is being examined, the investigator's questions and their answers should be recorded. For clarity, it is advisable to have a remote microphone attached to the investigator and the person giving the testimony. The end of the shooting should reflect all the positions of the final part of the protocol. Participants of the investigative (search) action watch the video, after which the film additionally removes the message from the investigator that all participants of the process have watched and listened to the video. Participants in turn indicate that everything is recorded correctly or make comments and additions as needed.

\section{CONCLUSIONS}

To summarize, it can be noted that the increase in the number of criminal offenses, the professionalization of crime in Ukraine, requires law enforcement agencies to significantly improve their criminal investigation activities. One of the areas of this activity is the introduction into the process of investigation of modern technical means and methods of collecting and investigating evidence. Today there are separate procedural, technical, methodological and other problems of participation of specialists in carrying out investigative actions. We have considered only some of them. Improving the organizational and tactical foundations of conducting investigative actions with the participation of specialists is a promising area of scientific research.

\section{SUMMARY}

The article deals with the problems of participation of specialists in investigative actions relevant to the investigation of criminal offenses today. This problem is related to the introduction into the process of investigating the latest scientific and technological 
progress and the scientific and technological means developed on their basis. Specialists are the main subjects of investigation, the rights and duties of which are defined by the Criminal Procedure Code, and which are precisely responsible for the implementation of science and technology in the investigation process.

The most important for investigative investigations are the location inspection, search, interrogation and investigative experiment. The article deals with the actions of specialists in carrying out these actions. Types of assistance of specialists are considered, namely forensic, advisory, methodical and technical activity. Special attention is also paid to the actions of specialists, depending on the stages of the investigative action: preparatory, working and final. Specialist actions aimed at detecting, fixing, and removing traces of crime are considered. The use of technical means is closely linked to the tactical methods of conducting one or another investigative action. Each of the investigative actions examines the technical means of recording evidence, such as the camera and camcorder, as well as the methods of photo and video shooting.

\section{REFERENCES}

1. Аверьянова Т. В., Белкин Р. С., Корухов Ю. Г., Россинская Е. Р. Криминалистика. Учебник для вузов. Под ред. Заслуженного деятеля науки Российской Федерации, профессора Р. С. Белкина. М. : Издательство НОРМА, 2000. 990 с.

2. Гончаренко В. И. Использование данных естественных и технических наук в уголовном судопроизводстве (методологические вопросы) : монография. К. : Вища школа, 1980. 160 с.

2. Кримінальний процесуальний кодекс України від 13.04.2012 p. № 4651-17. URL: http://zakon4.rada.gov.ua/ laws/show/4651-17.

3. Про затвердження Інструкції про порядок залучення працівників органів досудового розслідування поліції та Експертної служби Міністерства внутрішніх справ України як спеціалістів для участі в проведенні огляду місця події : наказ MBC України від 03.11.2015 № 1339. URL : https://zakon.rada.gov.ua/laws/show/z1392-15. 
4. Криміналістика : підручник для студ. юрид. спец. вищих закладів освіти. Кол. авторів : Глібко В. М., Дудніков А. Л., Журавель В. А. та ін. За ред. В. Ю. Шепітька. К. : Видавничій Дім «Ін Юре», 2001. 684 с.

5. A Simplified Guide to Crime Scene Investigation. National Forensic Science Technology Center, September 2013. URL: http://www.forensicsciencesimplified.org/csi/how.html.

6. Crime Scene Camera Kits + Reconstruction Software. CSI: 360: веб-сайт. URL: http://www.csi360.net/360-crime-scene-cameras.php (дата звернення 01.05.2019).

7. Весельський В. К. Сучасні проблеми допиту (процесуальні, організаційні і тактичні аспекти) : монографія. Київ : НВТ «Правник». НАВСУ, 1999. 126 с.

8. Чаплинський К. О. Тактичне забезпечення проведення слідчих дій : монограф. Д. : Дніпроп. держ. ун-т внутр. справ; Ліра ЛТД, 2010. 560 с.

\section{Information about the author:} Pyrih I. V.,

Doctor of Law, Assistant Professor, Professor Department of Criminalistics, Forensic Medicine and Psychiatry Dnipropetrovsk State University of Internal Affairs 72, Haharin av., Dnipro, Ukraine 